\title{
Nenglish: An Inevitable Reality or Merely a Mirage
}

Eak Prasad Duwadi

\begin{abstract}
Several discussions are being held on which variety of English to adopt and adapt to it around the world. Nepal, where modern English education began in the 1850s, is also at the crossroads because English teachers and practitioners here are in dilemmas whether to follow British/American versions, Hinglish (Indian variety of English) or their own Nenglish (Nepali Variety of English). Although there is a trend of developing local varieties around the world, some scholars are skeptic as this championing can lead to anarchy in a small developing country like Nepal.
\end{abstract}

Key words: Nenglish, Hinglish, received pronunciation, standard English

\section{Introduction}

Today many teachers opine that English is constantly changing so what is wrong now can be correct tomorrow; what can be taught today is what was heard yesterday; and teachers need to convey this to students so they will not experience shock in the future. Still scholars from around the world often choose Standard English as the most appropriate one to teach (Bex \& Watts, 1999). This refers to the teaching of a standard variety of English and discouraging the use of other types of English that may be termed as incorrect, inferior, or improper. There have been continual discussions on the kind of English in Nepal that an individual has to learn and acquire to be successful in the global market. Nepali English teachers are no exception. Often hot discussions are held on the type of English (not) to be taught in ELT classes.

The aim of this article is to discuss whether ELT teachers and practitioners can adopt Nenglish (Nepali variety of English) in Nepal. So I have analyzed the history of English in Nepal briefly. Then, I have discussed the status and (or) role of English in New Nepal. Similarly, the dilemmas on choosing the type of English for classroom purposes have been discoursed. Next, I have tried to see why Nepali ELT community has been practicing only Received Pronunciation though long ago Hinglish (Indian variety of English) was rooted in India which has strong sociocultural relations with Nepal. Finally, I have drawn some conclusions.

\section{History of English in Nepal}

Before entering to the topic Nenglish, how, why and when English entered Nepal is important to be revealed. Nepali statesmen like Prithvi Narayan Shah and Bhimsen Thapa tried their best not to let English flourish in Nepal; and their resistance to English remained unsettled for years. However, after the unification of Nepal, English slowly became widespread with different twists and directions. When Junga Bahadur Rana returned from Europe, he was thinking of new programmes, and one of them was educating his sons and grandsons in English. "After two years of his arrival from Britain in 1851, he arranged for two of the English teachers from Britain, to teach his brothers and nephews English on the ground floor of Thapathali Durbar" (Paudyal, 2009 ). The British might have had desires to influence the Rana rulers to adopt English in Nepal. Although Nepal was never colonized by British , the Ranas 
served them to guarantee their oligarchy in Nepal. To cite Paudyal (2009) again:

English in Nepali public school education system has traveled in fluctuating paradigms since it got formally imported in 1853. Its birth, growth and prescription has gone in parallel with the rise and fall of British imperialism in the South (India) and the changing political parameters of home. There are interesting facts, politics of exclusion and nationalism embedded in its history. (p. 6)

One of Nepal's closest neighbors, India, with whom she has been sharing sociocultural matters from the time immemorial, was occupied by the East India Company so the former could not remain unaffected from the changes that began occurring in the South. One of such transformations was adopting English education. In this, "Thomas Babington Macaulay appears to denigrate the value of Indian languages, elevate the qualities of English, and declare that English should henceforth become the medium of education in India” ( Graddol, 2010, p. 63). In 1835 he drafted a document in India which was known as Macaulay's Minute on Education, and that became the source for Nepali policy makers later.

For many educated Nepalis, Macaulay is an unforgettable name though he never came to Nepal. Instead Hugh B. Wood, US Fulbright Scholar and educationalist, on an assignment in India (Awasthi, 2008) was one of the first to imagine Nepal as becoming an integrated national entity one day. Following the visit of Wood who was appointed as the Educational Advisor to the Commission, the Government constituted the Nepal National Education Planning Commission (NNEPC), popularly known as the Wood Commission, in 1954 (Sharma, 1986 as cited in Awasthi, 2008, p. 22). He had similar thinking as Macaulay himself who seemed convinced that $e k$ bhasa ek bhesh (one language and one uniform) could ensure the Panchayat system (King's direct rule) in Nepal.

\section{English in New Nepal}

Nepal's cultural, religious and social ties, and educational links with India have existedsince the time immemorial, the effect of the Macaulay Minutes was far-reaching on the minds and lives of the people in Nepal. There are striking similarities between the two (Awasthi, 2008). Such concurrences might have continued till today. Phyak (2010) uncovers "The Rana's protection of English as the language of rulers, and the Panchayat's covert willingness to make it the language of elites clearly divided the society into two groups: the dominant English-literates and the dominatedEnglish-illiterates"(p.6). Consequently, the rich have the access to the knowledge industry and have been much benefitted.

With political changes, there have emerged many inclusive issues in Nepal, and one of them obviously is language policy. Even though the status of current lingua franca (Nepali) and, English (EFL) is not decided, promotion of local vernaculars is widely discussed in various forums. For example Phyak (2010) criticizes:
Although there is the provision of mother- tongue education, due to the socio-economic power ascribed to English, innocent children and parents are motivated to learn English while forgetting their own ethno-linguistic identity - which could have serious future economic and political implications. (p. 6)

There is such danger of elimination of Nepali and other indigenous languages unless proper policies are implemented. Bearing the same in mind, books on different languages like Tharu, Kirant, Newari and Maithali, etc were written. Some schools were selected to implement class in their own mother tongues as S. Toba, I. Toba and Rai (2005) argued:

Only recently, English schools have sprung up, first in the Kathmandu Valley and later also in other towns of the more outlying districts. Indigenous languages have been the medium of education only in a very few cases, that is, Newari (one school in the Kathmandu valley), some of the Kirati languages, namely Bantawa, Limbu (formal education), and Khaling (adult literacy, nonformal education). (p. 19)

Nonetheless, those programmes have not brought substantial results. The craze of English does not end there. English, which was once the language of 
rulers and elites, has now reached the mass from the urban locations to schools in the hills. It has become an indicator of "educatedness" (Paudyal, 2009, p. 6 ). Be it the rich or the poor, each class has tasted the fruits of English. Now there are thousands of graduates in the market who got exposure to English. Besides upgraded public schools, there are over 8 thousand English medium schools in Nepal. Karna (2006) concedes, "A large numbers of books, journals and periodicals are produced in English. Nepali literature - stories, essays and poems have been translated into English for wider readership". He has indicated the "golden era of Nepali media" that began from the mid 1990s has introduced different products like English broadsheets, radios (mostly FMs), and online editions which have accelerated the use of English. Moreover, stiff competition between English medium schools in Nepal has helped boost English in everyday life:

English medium schools have treated their territory as 'English speaking zones'. This has transformed the role of every teacher to be an English teacher first. A considerable number of interviews on TV take place in English. FM radio stations beam a good number of programmes in English". (Karna, 2006)

Be it print media or Internet, for both teachers and students, each provide much knowledge to them. Above professional organization like NELTA has been organizing annual conference every year when hundreds of Nepali English teachers and their counterparts from different parts of the world meet and share their experiences and pedagogies which not only strengthen their relationship but also update their English. Recently, Nepali writers have begun to write some course books. Bhattarai \& Gautam (2005) adds:

The crave for English has grown so much that by now within a span of three decades there are large number of famed publishing houses that produce materials (textbooks) in English, these are prepared mostly by native (Nepali) writers and editors, there are different training institutes and their training centres, different teams of writers, translators, trainers, all for promoting
English all engaged in ELT enterprise. (p. 1)

In spite of signing MDGs (Millennium Development Goals), opening thousands of more schools (mainly in big cities and town), and also campaigning for admitting every child in a nearby school, but a chunk of Nepali children are still far from the light of education and they don't have any way to learn English and other source of education.

Although the chronicles of English in Nepal might seem a simple one, the story is actually more knotty, and is still ubiquitous today. Paudyal (2009) agrees on it:

Little can be said with certainty about curriculum and syllabus design of English as a subject since, until 1971, Nepal did not have an official body to administer and monitor school curriculum. [.....] In what may sound strange, National Education system plan of 1971 again deleted English as a "compulsory subject" from the primary school curriculum (class I to III) and relegated its status to "one of the UN languages" as a compulsory subject in lower secondary and SLC curriculum. This time it was a single paper with 100 marks. And it did not necessarily have to be English. Call it coincidence or politics, 1971 is one of the years of Panchayat heydays, which defined Nepali nationalism in opposition to everything foreign. From 1981 onwards, however, English has been kept as a compulsory subject in high-school curriculum.

Nepal adopted different policies for English education at various stages of time. Sometimes English was started from class four and other time from class one. However, this is never a question for elites who have been sending their children to privately run schools (commonly known "Boarding Schools") where they teach English from Pre-Primary Level. "Despite the long domination of the Nepali language, now English has been introduced from grade one in schools without any intensive research" (Phyak, 2010, p. 6). Despite this rupture, some scholars have buttressed on that English has been uplifted distinctively. For example, one researcher states:

Until recently, English was taught as 
a foreign language. Nevertheless, its enormous demand and use have made it a second language. Today, English is not only a subject taught in the academic institutions but is also a medium of instruction, means of communication between students and teachers, and the language of trainings, seminars and conferences. (Karna, 2006). People having access to English have achieved more. Nepalis also have realized this. Besides being one of the most dominant international languages, English has become world language now. The fact that English is becoming Second Language from its English as Foreign Language status proves its development in Nepal.

In government schools the children have to study one English subject and other subjects are in Nepali. Therefore, most of the children learning in governmental schools don't know how to speak and write nicely. However, the middle class families and high class families of Nepal prefer to send their child to Private schools as they all other subjects in English except one Nepali. The children of private school especially from Kathmandu, Pokhara and Biratnagar have a good command in English, but schools in other cities may be good in writing and no good command in speaking.

\section{Concept of Standard English}

Even after having seen the rise of World Englishes, there are hot discussions on what type of English Nepal should adopt. Some Nepali scholars and practitioners opine for either American or British English. There is equal number of intellectuals who prefer Hinglish or Nenglish to those. According to the former intellectuals, Nepal cannot develop its own variety of English because of limited resources and small population. The latter bunch of intellectuals, however, gives emphasis to the changes in world power equations. Phyak (2010) asserts, "In Nepal, we are trying to make our students monolingual speakers of English through the overemphasis on the language in our education system" (p. 6). He thinks English is killing local dialects, harming indigenous lives and cultures, but other scholars even began rationalizing Nepal can embrace Hinglish as India and Nepal share many things in common. "The influence of Hinglish can easily be noticed in the English used in the SAARC countries and Nepal is not an exception. However, English used in Nepal or Nenglish shows striking evidences from Hinglish" (Rai, 2006 as cited by Karna, 2006, p. 76). Like Indian economy and culture, Hinglish has made some effects in the use of English in Nepal. Failing to do so in past (only following British and/or American pronunciations) hindered the progress as most of the Nepali students who lack wider English exposures could not get anticipated benefits.

A participant in a NELTA conference revealed to the author, "My students cannot understand the accent so even local audio/video materials are irrelevant in remote parts of Nepal". Phyak (2010) states, "I hypothesize that one day we will have a separate variety of English. This may emerge with the publication of more textbooks and material in Nepal by local authors and writers instead of importing of books from abroad" (p. 6). He is not the only one to be so optimistic on getting Nenglish standardized:

The Nepali variety of English, or Nenglish, shows not only remarkable disparity from the native dialects like British, American varieties but also from the Indian English, comically known as Hinglish (as it is influenced immensely by the Hindi language). As a matter of fact, English spoken in Nepal has considerably changed over the years. It has been observed that the way Nepalis speak English differs from the way other nationals speak, not only in terms of vocabulary but also structure and meaning and pronunciation. (Karna, 2006)

Besides Nepali scholars, many other foreign English practitioners have also advocated a local variety. Gairns and Redman (1992) agree "A language cannot be taught without taking into account its sociocultural system: appropriateness of language, gestures, social distance, values, mores, taboos, habits, social institutions, registers, dialects, and so forth. For example, while teaching vocabulary, teachers have to decide what sociocultural factors are involved" (p. 59). Markee (2010) emphasizes the need for discussions on appropriate measures to protect the country's 
linguistic and cultural heritage from the potential killer characteristics of English. Otherwise, as 19th century philosopher Antonio Gramsci says, English will only become the symbol of hegemony (Phyak, 2010). It is obvious that in the Third World countries the choice of functions, uses and models of English has to be determined on a pragmatic basis, keeping in view the local conditions and needs (Kachru, 1976, p. 236). In Cook's (1999) words:

L2 learners' battle to become native speakers is lost before it has begun. If students are convinced of the benefits of learning an L2 and recognize their unique status as standing between two worlds and two cultures, more students may go on higher levels of L2 use; those who do give up may feel more satisfied with the level of L2 use they achieve. (p. 204)

It seems futile to practice on such method which is not practical. Taking an objective of making L2 learners as L1 is also such attempt that has failed in different parts of the world. Instead of only making copy cats, ELT teachers in the third world ought to let students think and produce by giving them an eclectic environment as Canagarajah (2009) maintains:

Plurilingual competence does not mean that students cannot produce 'standard' language for formal production when the context requires it (as I have argued elsewhere, see Canagarajah 2006). The heightened language awareness and multilingual proficiency can create a keen awareness of language norms and contextual appropriateness of usage. In other words, plurilingual competence does not mean disrespect for norms and conventions, but the ability to critically and creatively engage with them. (pp. 21-22)

Addressing 13th International Conference of NELTA, Briggs (2008) asserted "that on the one hand, methodology has been the central issue in ELT discourse, on the other, the methodology borrowed from BANA (British, American, New Zealand and Australian) settings has not always been compatible in the local context". When sociocultural and geopolitical conditions are not taken in consideration, expected outcomes will be always insignificant because, local knowledge has a legitimate place in the ELT curriculum in Nepal.
I agree with Graddol (2006) who claims there is an extraordinary diversity in the ways in which English is taught and learned around the world ( $p$. 80). Understanding what (Non) Standard English is is not easy as there are deviations in vocabulary, syntax and pronunciation for the time being. For Trudgill and Hannah (1994) the term "dialect" usually refers to diversity in the varieties of a language in which vocabulary, syntax, and pronunciation may change. For example, British and American English are two different dialects, with differences in lexical items (e.g., lift/elevator, petrol/ gasoline, bonnet/hood, truck/lorry), syntax (the past tense of the verb to learn: learned/learnt), and phonology (pronunciation).

Dialects are also found in other languages, for instance the Spanish dialect used in Mexico compared with the Spanish dialect of Argentina, in which features such as verb conjugations and some word meanings vary. Trudgill and Hannah also compare the concept of dialect with "accent", explaining that the latter merely refers to differences in pronunciation within a language. Lippi-Green (1997) explains that geographical location is often used as a boundary to mark different accents (e.g., a Chicago accent). Nevertheless, other features may be used to mark boundaries as well, such as social class, gender, or race. These may also mark different dialects, if there is variation in other language components, such as different vocabulary or sentence structure.

Trudgill and Hannah (1994, p. 59) further explain two approaches in linguistics have existed historically-- (a) "prescriptivism", a view that favors a certain dialect to be used and "prescribed," a standard form of language, and (b) "descriptivism", a view that focuses on diversity in language and the description of language without placing a higher value on one range over another. Crystal (2008, p.60) has written that "grammarians" in Europe studied languages from a perspective in the 18th century, in an attempt to label language use as "correct" or "incorrect", establishing grammar rules. He highlights the role of language academies in keeping the use of language "pure," such as in the case of France, Spain, or Italy.

The idea of a standard language to be prescribed 
implies aspects of power that are not intrinsic to the linguistic structures. They have to do with conferring legitimacy on the language variety spoken by dominant groups in a society, as Bourdieu (1991) explains. In the case of English, Trudgill and Hannah explain that the variety known as "standard" was used by the upper classes and became the model to imitate. "Standard English", he stresses, "is one dialect out of many, the dialect associated with educated and powerful people" (p. 59).

I agree with Pakir (1999) who indicates, "English must not fail the test. Nor should teachers of English, whether from the Inner Circle, the Outer Circle, or the Expanding Circle, because internationalization is no longer optional but inescapable" (p. 113). Nonetheless, Lippi-Green (1997) regards the notion of a standard language as a myth. She argues that the ideology supporting the existence of a standard language emphasizes the ideal of a homogenous language form and its role in a "nation-state", allowing a certain group to control language variation. She also notes "that it allows for other dialects to be labeled as "nonstandard" or "substandard." Similarly, Labov (1978) has conducted several researches analyzing dialects that were categorized as "nonstandard' by establishing that they were not to be regarded as inferior to the "standard dialect". He argues 'that they are language systems that are different but closely related, with functional grammatical processes of their own". For example, in African American colloquial English (also known as Ebonics), the form "be" signals habitual general conditions, as in the example Labov gives-- "He always be foolin' around."

It should not be seen as a mistake when compared with Standard English and the use of "is" or "am". The use of "be" is a syntax rule that is valid and consistent in this particular dialect. Other English varieties, such as "Spanglish" in the United States or "Hinglish" (Indian English), have been analyzed similarly, as in the work of Poplack and Kachru (2008, p. 60), respectively. Not only are these varieties rule governed, they also play a significant role as identity indicators for their language communities.

\section{Selection of English in Classroom}

Cab or Taxi? Colour or Color? Socks or Sox? Organisation or Organization? Underground or Subway? Gas or Petrol? Fall or Autumn? Candy or Sweets? Cookie or Biscuit? Centre or Center, Trash or Rubbish? Film or Movie? Travelling or Traveling? Not only students but also teachers get confused because there are different varieties of English around us nowadays. Recently a nine year old nephew came with loads of GRUMPIES. He was very angry and blamed me for that because I had recommended him to write color, mall and traveling instead of colour, shopping centre and travelling respectively. I tried my best to induce him but he did not believe me. Now thinking my English is faulty, he avoids me when he studies as his English Language teacher has crossed those in red.

Another day, I called on my school teacher, coordinator of a +2 school. I produced my resume before him to apply for the post that was going to be vacant. He started wincing his face as soon as he had a glimpse on it, "You do not know how to write Bio Data," he stood up and checked his shelves and added, "had I got one sample, I would have shown you!" He broke our conversation making an excuse.

British have been using 'Pakis' to adress Pakistanis for a long time. At the time of sweeping Taliban rules from Afghanistan, the former US President George Bush once called Pakistani people 'Pakis', they felt so insulted that they condemned Bush in public. After three years 'Pakis' became so common that not only the western but also Pakistani people started to use it comfortably.

What is the difference between BANA (British, American, New Zealand and Australian) English varieties? This is the question every English teacher would like to find out now. According to a professor in English, there is no difference, "Whether they are British, American or African English, they use the same," he adds "but there are good and bad Englishes". But when a student writes program instead of programmes do we accept? There are so many differences particularly in spellings. Moreover there are hundreds of words which are quite unlike to each other for example holiday and vacation. In addition to 
that there are some differences in their tones. A father who teaches English in a missionary school in Nepal opines, "Being a language teacher we should recognize any standard one". He has even suggested that change is inevitable. "I don't like some of the American rules though I am an American for he/she Americans use they," argues an American Professor. "It's me instead of It's I," he added when I was talking to him. A Canadian who is an English language instructor gets amazed hearing our American version "In my country we prefer British to American English".

Not only I am in dilemma to choose an English type in class, but also native speakers themselves, "The frequency figures from the New York Times and the Independent for 1990-2000 show that the use is increasing in both varieties; they also suggest that British English has caught up with and passed American English, at least in the Press" (Lindquist, 2007, p. 113). I also get confused when my students often use JPT (Jey Payo Tehi) instead of claptrap. Well, JPT has apparently become an English word among the high school and undergraduate students in Kathmandu.

Trudgill and Hannah (1994) discuss the (statistical) British-American divergence involving from and than. Recently than has become common in BrE (Crystal, 1984). Trudgill and Hannah also note that to does occur in the UK; and of course both from and than occur in Australia (p. 117). Selection of English in the classroom is not easy for each teacher as they are in dilemma which one to be adopted. Some scholars emphasize the importance of regional English where as there are other researchers who negate this. Labov (p. 48) emphasizes the educational disadvantage of Black and Spanish-speaking students in urban areas. He stresses the need to understand English varieties used by these communities -in the latter, what he called "Spanish-influenced English"-since using them was the best way of communication with these children and young people. In addition to importance of this knowledge to build bridges between speech communities, favoring and accepting Standard English as the only "correct" variety works to reproduce and strengthen its dominant status in society, a role that the educational system has supported for many centuries.
Gee (2008) addresses the impact of not mastering the ways to use language favored at school for linguistic and culturally diverse students. He gives the examples of African American students whose ways to use narratives in which they have been socialized at home are not valued when brought up at school. He stresses their disadvantage compared with children who have been exposed to academic language before starting school, as part of their socialization at home. For educators, this situation demands ways to build bridges for students whose first encounter with different ways to use language happens at school. Cazden's (2001), work addresses the functions of classroom discourse, analyzes this dilemma faced by many teachers in negotiating language attitudes held by students and teachers. She recommends "that the contrast of dialect forms and the conceptualization of the use of "proper" language as a practical and political matter, instead of a judgment of what is right or wrong-hence considering the convenience of language features appropriate for a particular audience but also questioning and reflecting on the power issues attached to the hierarchical status of standard varieties" (p. 34).

Delpit (1988) stressed the need for every student to learn the "codes of power-- ways of talking, writing, or interacting, for example" (pp. 379-385). She suggests when addressing language varieties that students need to learn the variety of power and that schools should take the responsibility to assist them in this process. However, it is necessary to analyze how the codes of power are arbitrary: not better because of intrinsic features, but due to the power associated with them. She described the case of a Native Alaskan teacher who addressed the differences between the "village English" the students spoke in their community and the "formal English" they needed to communicate with those whom she labeled "people who only knew one variety."

Fecho, Davis and Moore (2008) have confirmed the need to involve their students in academic issues analyzing the social and political nature of language. In their work with African American students, they explored their "switch" to Standard English for particular written tasks and discussed with them the implications of appropriating a standard variety for certain audiences and 
purposes-for example, how using Standard English did not necessarily imply adopting "White values". They also questioned and rejected the idea that Standard English was a "universal" language or that using this dialect signaled superior intelligence (p. 61). Graddol (2006) also concedes, "Often, there exist local as well as ethnic varieties of English" (p.85).

Whether students are speakers of different varieties of English or languages other than English, the concept of a standard language and its implications should be part of conversations with them about the social, cultural, and political aspects of language. The acknowledgment of different language varieties, their use, and their role in the identity of speech communities play a crucial role in the building of bridges between home and school language practices; but opportunities to analyze, discuss, and be apprenticed to the language variety of power are also instrumental for linguistic minorities to understand the role of standard English in academic environments.

At a global scale, where English is taught and widely used as an international language (the world language?), similar conversations should take place between nations and societies. Different varieties of English are used and appropriated for specific purposes outside the USA, the UK, Canada, or Australia. Situating the role and power of Standard English among other varieties may allow for critical use and understanding for language learners, as opposed to the obligation of a "standard" type of English to be used.

\section{Only Received Pronunciation}

British and/or American English has been taught in Nepali schools and colleges though it was never colonized. India is the country which has the relation of beti and roti (daughter and bread) with Nepal, unlike other politico-historical contexts, unsurprisingly, Indian English (Hinglish) has very little impact in the English used in Nepal.

Nepalis were influenced largely by what happened in India-independence from Britation as a colony. Nepal's first SLC batch graduated in India, English teachers mostly graduated from Indian higher education boards came to different parts of Nepal and taught English. On the contrary, instead of implementing what they learnt in India, they adopted Received Pronunciation (a pronunciation of British English, originally based on the speech of the upper class of southeastern and characteristic of the English spoken at the public schools and at Oxford and Cambridge universities; until recently it was the standard form of English used in British broadcasting) in education courses to produce secondary school teachers who in turn exposed British variety for many decades. Textbooks, trainings, and workshops etcetera were also no exception. They were either in British or American variety.

Most of Nepalis students acquainted with English from the primary school curriculum (from class four), with learners rarely starting study before the age of 11 or 12 . They have focused on such things as grammatical accuracy, native-speakerlike pronunciation, and literature.

When measured against the standard of a native speaker, few EFL learners can be perfect. This is the reason why native English teachers are more preferred in the western countries like America and Europe but also in many countries of Asia and Africa. "Within traditional EFL methodology there is an inbuilt ideological positioning of the student as outsider and failure - however proficient they become" (Graddol, 2006). Be it internal conferences or workshops, participants rush to the concurrent sessions run by the native speakers although their counterparts who are non-native but could have equal or more expertise and experiences are doing concurrent sessions in next halls.

Whatever stage English is started from, the main objective was and is the same in Nepal-fluency in English. They have always expected glib level of formality written, reading and spoken English as same as the native speakers have. Whether the goal has been achieved is another domain of research, but knowingly or unknowingly Nepalis have preferred Received Pronunciation to local or regional one. Earlier British English (BE) was considered the sole model for learners of English in most countries of the world (Benson, 1989), including Nepal.

I think there are many reasons behind it. First of all, although British left India in 1947, their control and dominance remained there. Being colonized 
for more than three centuries, many Indians mind was washed; and after Sugauli Treaty, Nepali sentiment was also marred-many patriot Nepalis became lahures by serving the British as brave Gorkhas. Therefore, not only the elites but also middle-class Nepali could not dare adopt regional variety of English. Moreover, prejudice was partly responsible for that because Nepalis perhaps did not trust Indians fully. Even Indian teachers could not discard British influence as there existed publishers like Cambridge University Press and Oxford University Press which continued gaining reputations. Institutions like British Council, many missionary schools/ colleges and universities are also hugely responsible for the spread of Received Pronunciation in India and his special neighbor Nepal. Above all, Nepal's education policies were induced or made either by the British or American experts like Macaulay Minute and Hugh B. Wood.

Earlier, British English was the role model, but with the paradigm shift of economy and power to the United States of America, American English has begun larger appearance in Nepali Education system (mainly in higher education). Equally important is many of those teachers in Nepal also prefer Nenglish (Nepali variety of English) to the standard ones. However, it is too early to speculate the execution of local variety because even Australia, India and New Zealand had to struggle for centuries to make their varieties be recognized.

Since other variations are merely modifications of either of British or American English, I think, teachers ought to teach these first. As the result, learners can adapt any other varieties like Indian English (Hinglish) or African English. Moreover, if each country or community starts to develop their own English, there will be more confusions. And again, standard form will be sought - that will be no different than the English that the superpower country, which is also world economy, uses. However, my views sometimes spark fires among many English Language teachers and practitioners so they poke me with several sociopolitical, cultural and economical issues.

Several studies show that teaching Standard English may well be the best choice, but knowing why we choose to teach it is equally important for both students and teachers alike. Equally vital is for students to understand that the continuation of nonstandard forms is a natural phenomenon in all languages. Moreover, it is important to value them and the people who speak them. Similarly, English language teachers should know that teaching/learning English is a challenging task because what can be taught today is what was heard yesterday; what is wrong now can be correct tomorrow; and they should convey this to students.

\section{Conclusion}

People having either British (and) or American Standard English get preferences in almost every job in Nepal even today. Be it news anchoring on television or teaching in colleges, fluency matters more. Private schools and colleges often advertise pompously showing the photographs of Whites who are so-called faculties there, even name of such institutions are borrowed from the West. If someone comes back from abroad, s/he gets offers and privileges in any sector simply because of their pronunciations. I am not talking about the western countries, even in Nepal, India and China; Whites are sought but non-Whites whether the vacancy is for teaching or running workshops. Whether to go to America, the UK, Australia, Canada or New Zealand for studies, one should take TOEFL, GRE, IELTS, GMAT, SAT etc and score high in one of these exams. In spite of better infrastructures and human resources non-missionary schools cannot attract sizeable number of students. All these happen as English belongs to them certainly.

Interestingly, some scholars have been arguing for either Hinglish or Nenglish recently. Their claim is that English being (the) world language allows them to deviate from the standard variety. Doing so I think only brings chaos in our community. Not only Nepal has to pay unnecessary attention but also invite another social calamity as to unlearn the local variety and learn Standard English, the learners have to unlearn everything-Nepalis have hire more Macaulay Minutes and Dr. Woods to resurrect English. This is the reason why Received Pronunciation is all time favorite in Nepal.

Be it American or British, each English is like thief (here very flexible) which steals words from other 
languages so they have been changing themselves. Making Nenglish campaign is, thus, proved to be impracticable. Perhaps the campaign for developing alternative varieties is the boomerang catapulted by some native masterminds which has been designed in such a way that paralyses the abilities of non-native English speakers, so that they can reclaim their importance and later sell Standard English to the country like Nepal which is very dependent. If we want change in Nepal, we can give different varieties of Nepali so that every language group can communicate effectively. Let's leave English as English.

Eak Prasad Duwadi is a Lecturer at the Department of Languages and Mass Communication, School of Arts, Kathmandu University, Dhulikhel. He has presented papers in different conferences and published articles in different journals.

\section{References}

Awasthi, L. D. (2008). Importation of ideologies: From Macaulay minutes to Wood commission report. Journal of of education and research, 1(1), 21-31.

Bex, T. \& Watts, R. J. (1999). Standard English: The widening debate. New York: Routledge.

Benson, M. (1989). Differences between American English and British English: A challenge to TESOL. TESOL Quarterly, 23 (2), 351-355. Retrieved July 18, 2010, from http://www. jstor.org/stable/3587357

Bhattarai, G. R., \& Gautam, G. R. (2005). English language teachers at the crossroads. Journal of NELTA, 10 (1-2), 1-5.

Bourdieu, P. (1991). Language and symbolic power. Havard: Havard University Press.

Briggs, S. J. (2008). Think globally, act locally. Global change and local realities: addressing the local methodological isues. Kathmandu: NELTA.

Canagarajah, S. (2009). The plurilingual tradition and the English language in South Asia. AILA Review, 22, 5-22. Retrieved July 18, 2010, from http://www. doi 10.1075/aila.22.02can

Cazden, C. (2001). Classroom discourse: The language of teaching and learning. London: Parson.

Cook, V. (1999). Going beyond the native speaker in language teaching. TESOL Quarterly, 33(2), 185-209. Retrieved July 18, 2010, from http:// www.jstor.org/stable/3587717

Crystal, D. (2008). Grammarian. In Encyclopedia of bilingual education. New York: Sage.

Delpit, L. (1988). Codes of power. Harvard Educational Review 56(4), 379-385.

Fecho, B. , Davis, B., \& Moore, R. (2008). Social and political nature of language. In Encyclopedia of bilingual education. New York: Sage.

Graddol. D. (2006). English next. London: British Council.

Graddol. D. (2010). English next India. London: British Council.

Gee, J. (2008). Social linguistics and literacies: Ideology in discourses. London: Routledge.

Kachru, B. B. (1976). Models of English for the third world: White man's linguistic burden or language pragmatics. TESOL Quarterly, 10(2), 221-239. Retrieved July 18, 2010, from http:// www.jstor.org/stable/3585643

Karna, S. K. (2006). ELT survey: Need of the country. Retrieved August 18, 2010, from http://www. gorkhapatra.org.np/detail.php?article id $=1124 \&$ cat_id $=7$.

Karna, S. K. (2006). English: Then, now and the day ahead. Journal of NELTA, 11 (1\& 2), 73-79.

Labov, W. (1978). The study of nonstandard English. London: Parson.

Lindquist, H. (2007). Viewpoint: The spread and development of a new type of adverb in American and British English. Journal of English linguistics , 35 (2), 132-137.

Lippi-Green, R. (1997). English with an accent. London: Routledge .

Matsuda, A. (2003). Incorporating World Englishes in teaching English as an international language. TESOL Quarterly, 37 (4), 719-729. Retrieved July 18, 2010, from http://www. jstor.org/stable/3588220.

Pakir, A. (1999). Connecting with English in the context of internationalisation. TESOL Quarterly, 33(1), 103-114. Retrieved July 18, 2010, from http://www.jstor.org/stable/3588193

Paudyal, M. (2009, July 19). English in Nepali education system. Republica, p. 7. 
Phyak, P. (2010, September 9). To speak or not speak. The Kathmandu Post, p. 6.

Poplack, S. , \& Kachru, B. (2008). Best English to learn. In Encyclopedia of bilingual education. New York: Sage.
Toba, S., Toba, I., \& Rai, N. K. (2005). Diversity and endangerment of languages in Nepal. (L.N. Pathak, Trans.) Kathmandu: UNESCO.

Trudgill, P., \& J. Hannah (1994). International English: A guide to the varieties of standard English. New York: Sage. 